\title{
Effect of freezing on the rheological, chemical and colour properties of Serpa cheese
}

\author{
Nuno Alvarenga ${ }^{1 *}$, João Canada ${ }^{1}$ and Isabel Sousa ${ }^{2}$ \\ ${ }^{1}$ Polytechnic Institute of Beja, Escola Superior Agrária, ADCTA, Rua Pedro Soares, Apartado 6158, 7801-908 Beja, Portugal \\ ${ }^{2}$ Technical University of Lisbon, Instituto Superior de Agronomia. Tapada da Ajuda, 1349-017 Lisboa, Portugal
}

Received 8 February 2010; accepted for publication 24 September 2010

\begin{abstract}
The effect of freezing on the properties of a raw ewes'-milk semi-soft cheese (Serpa cheese) was studied using small amplitude oscillatory (SAOS) and texture measurements, colour and chemical parameters. The freezing was introduced at three different stages of the ripening process $(28,35$ and 42 days), and the cheeses were maintained frozen for 12 months. Cheeses were submitted to a slow or fast freezing method, and to different storage temperatures: -10 and $-20{ }^{\circ} \mathrm{C}$ (three replicates for each set conditions). Chemical data showed that only the proteolysis indicators exhibited differences between frozen and non-frozen samples; frozen samples showed higher values of NPN than the non-frozen samples, indicating that the freezing process did not prevent the secondary proteolysis of cheese. Frozen samples showed a significantly $(P<0.05)$ stronger structure than the non-frozen, as indicated by hardness. However, the differences between the frozen and non-frozen samples were not significantly for storage modulus $\left(\mathrm{G}^{\prime}{ }_{1 \mathrm{~Hz}}\right)$ and loss tangent $\left(\tan \delta_{1 \mathrm{~Hz}}\right)(P>0 \cdot 05)$. Freezing affected mainly colour parameters: frozen samples were more luminous, and more yellow-green. The results allowed us to conclude that the damages caused by freezing to cheese properties could be minimized if this type of storage is introduced at the end of ripening ( $42 \mathrm{~d}$ ) using a freezing temperature of $-20{ }^{\circ} \mathrm{C}$.
\end{abstract}

Keywords: Serpa cheese, ewe, freezing, rheological properties, proteolysis.

The seasonal nature of sheep milk production for the manufacture of traditional cheeses, and the high temperatures recorded in southern European Mediterranean countries, restrict the time for the production of these cheeses from October to June. Furthermore, milk production increases sharply in springtime and the sales peak of this type of cheeses is in the winter time at Christmas (Tejada et al. 2002). Freezing can be a suitable procedure to overcome this limitation, since it prolongs stability and shelf-life of the cheese. However, Fennema (1972) pointed out the lack of unanimity on the extent of damage to cheese caused by freezing. Damage depends on the type of cheese involved (composition, manufacturing procedures), the freezing conditions and the parameters chosen to evaluate the damage.

Recently, some studies about freezing ewes'-milk cheeses have been published. In these studies, the parameters chosen to evaluate the impact of freezing on cheese characteristics were: the fatty acid profiles (Zhang et al. 2006), the compositional analysis (Tejada et al. 2002; Prados et al. 2006), the nitrogenous and protein fraction (Fontecha et al.

*For correspondence; e-mail: bartolomeu.alvarenga@ipbeja.pt
1993; Tejada et al. 2002; Prados et al. 2006), the microbiological evaluation (Tejada et al. 2002; Prados et al. 2006), the texture analysis (Bertola et al. 1996; Van-Hekken et al. 2005) and the sensorial evaluation (Tejada et al. 2000; Prados et al. 2006). However, few authors have studied the effect of freezing on viscoelastic behaviour of these cheeses. Some of these authors argue that the variations that occur during the freezing have little effect on the rheological properties of the cheese (Van-Hekken et al. 2005; Ribero et al. 2007), while others maintain that a cheese softening can be observed in frozen cheeses, due to microbial lyses and to the concomitant release of proteolytic enzymes (Graiver et al. 2004).

"Serpa" is one of the most appreciated Portuguese raw ewes'-milk semi-soft cheeses (RESS-cheese) and it is produced in the south-eastern region of Portugal, being an important manufactured product, with high added value. It is a creamy, full fat (fat in dry matter between $45-60 \%$ ) and semi-soft cheese, originated from a slow curd syneresis after coagulation with a vegetable rennet infusion from the flower of the Cynara cardunculus L. plant. For the consumer, the most important feature of RESS-cheeses is the creamy mouth feel attribute. 
The structural properties of cheese can be described by its viscoelastic behaviour and are mostly dictated by the properties of the continuous network formed by the protein crosslinks (Zalazar et al. 2002). Measurements using small amplitude oscillatory stress (SAOS) allow the quantification of the elastic and viscous contributions to the cheese properties. Elastic response in cheese is primarily due to the protein-protein bonds. In contrast, the viscous dissipation in cheese may be due to the lubrication effect of fat on this matrix material (Park, 2007).

Cheese texture is affected by factors that determine structure, such as milk composition, moisture content, salt, $\mathrm{pH}$ and degree of proteolysis during ripening (Cunha et al. 2006). The hardness and storage modulus $\left(\mathrm{G}_{1 \mathrm{~Hz}}^{\prime}\right)$ are the most adequate indicators of the RESS-cheeses softening process during ripening (Alvarenga et al. 2008) and these are expected to be also important to detect some damage to cheese caused by freezing.

The aim of this study was to assess the effect of freezing on the chemical and physical properties of RESS-cheeses, namely Serpa cheese, at different stages of its maturation process (e.g. ripening), which will contribute to a selection of freezing conditions that would minimize the damages caused by this type of storage on the cheese properties. Compositional properties, namely major components, proteolyses indicators and $\mathrm{pH}$, were determined in order to evaluate the effect of freezing on the chemical characteristics; colour and rheological measurements (SAOS and hardness) were used to evaluate the effect on the physical characteristics.

\section{Materials and Methods}

\section{Experimental design}

Serpa cheeses were manufactured from slow curd syneresis, after raw ewes' milk coagulation $\left(30{ }^{\circ} \mathrm{C} / 45 \mathrm{~min}\right.$ ) with a C. cardunculus L. flowers infusion. The cheeses were made from 200 I milk, obtained on the same day of milking. Salt (ca. $1500 \mathrm{~g} / 100$ I milk) was added in two different phases of the cheese production: half of the amount was added to the milk and half was added to the curd, just before moulding. The curd was pressed and subjected to ripening, performed in two successive controlled rooms: two weeks of ripening performed in a controlled temperature $\left(8-9{ }^{\circ} \mathrm{C}\right)$ and relative humidity (92-97\%) room and, afterwards, in a second ripening room, at $10-13{ }^{\circ} \mathrm{C}$ and at $85-90 \%$ relative humidity (Roseiro et al. 2003). Ripened cheeses have a cylindrical shape with ca. $800 \mathrm{~g}$ each, $15 \mathrm{~cm}$ diameter and $5 \mathrm{~cm}$ height, and develop a yellowish rind during the ripening process. Ripening was interrupted, by freezing the samples, at different stages: 28, 35 and $42 \mathrm{~d}$ of ripening. A group of non-frozen samples were used as the control and analysed immediately after the ripening process. The other cheeses were maintained frozen for 12 months. After that, cheeses were thawed at $4{ }^{\circ} \mathrm{C}$ during $3 \mathrm{~d}$. The samples that were frozen at the $42 \mathrm{~d}$ of ripening were analysed immediately after the thawing process. The samples that were frozen with an incomplete ripening process, at 28 and $35 \mathrm{~d}$, were transferred to a ripening room (10-13 $\left.{ }^{\circ} \mathrm{C} / 85-90 \%\right)$ in order to complete the $42 \mathrm{~d}$ of ripening (for 14 and $7 \mathrm{~d}$, respectively) and after that, they were analysed.

Cheese samples were submitted to different freezing methods (slow or fast), at two different storage temperatures: -10 and $-20{ }^{\circ} \mathrm{C}$. The slow freezing method was carried out in a normal freezer $\left(-20^{\circ} \mathrm{C}\right)$ and the fast freezing was carried out in a forced convection ultra-freezer at $-30{ }^{\circ} \mathrm{C}$. The samples were kept frozen using a long time span (12 months), which was anticipated to cause measurable damage to the cheese properties. In each set of conditions, three cheese replicates were used $(n=3)$.

The samples were codified as: NF, 10F28, 20F28, 10S28, 20S28, 10F35, 20F35, 10S35, 20S35, 20F42 and $20 S 42$ (NF-non-frozen; 10 and 20 -frozen storage temperature, $-10{ }^{\circ} \mathrm{C}$ and $-20{ }^{\circ} \mathrm{C}$, respectively; $\mathrm{F}$-fast and $\mathrm{S}$-slow freezing; 28, 35 and $42-d$ of ripening). Due to an energy failure in the facilities, the $-10{ }^{\circ} \mathrm{C}$ freezer stopped and the samples $10 \mathrm{~F} 42$ and $10 \mathrm{~S} 42$ were lost.

For colour and texture determinations, $1 \mathrm{~cm}$ layer of the upper surface of each cheese was removed in order to expose a homogeneous surface of the inside. When needed, a cheese portion (approximately $0.15 \mathrm{~kg}$ ) was removed and preserved at $4{ }^{\circ} \mathrm{C}$, in a Petri dish, to be promptly used in the rheological measurements.

\section{Chemical characterization}

Moisture content and total nitrogen (TN) were determined according to the Association of Official Analytical Chemists' methods (AOAC, 1990), and were expressed in \% (w/w). In addition, $\mathrm{pH}$ was measured using a penetration electrode (Metrohm, Switzerland) and fat content through the Van Gulik method (ISO 3432, 1975). Water soluble nitrogen (WSN) was quantified performing an aqueous extraction of the N-components (Kuchroo \& Fox, 1982), followed by nitrogen determination using the micro-Kjeldahl method using a Kjeltec System 1030 distilling + titration unit system (Tecator, Höganäs, Sweden). Non-protein nitrogen (NPN) was determined by the $\mathrm{N}$-component precipitation with a trichloroacetic acid solution $\left(1 \cdot 2 \mathrm{~g} \mathrm{~kg}^{-1}\right)$ and $\mathrm{N}$ determination of the filtrate (filter paper Whatman No. 42) using the micro-Kjeldahl method (Freitas et al. 1997). Aminoacidic nitrogen (AN) was determined by the ninhydrin method (Pearce et al. 1988). Experimental data generated for the various soluble nitrogen fractions were expressed as a percentage of $\mathrm{TN}$, and used as ripening indices: ripening extension index, WSN\%; ripening depth index, NPN\%; and free amino acid index, AN\% (Férnandez-Salguero \& Sanjuán, 1999; Pereira et al. 2008). All chemical analyses were performed in triplicate.

\section{Dynamic rheology}

Rheological measurements were performed at $20 \pm 1{ }^{\circ} \mathrm{C}$ using a controlled-stress Rheometer RS-75 (Haake, 
Germany), with a parallel plate geometry of $20 \mathrm{~mm}$ diameter, serrated, in order to prevent slippage (Rosenberg et al. 1995). A stress sweep determination was performed on a different aliquot to ascertain linearity. All frequency sweeps were conducted at a constant shear stress of $50 \mathrm{~Pa}$ with oscillation frequencies ranging from 0.001 to $100 \mathrm{~Hz}$ in three different samples (triplicate). The output of the rheometer measurements was the variation of storage modulus $\mathrm{G}^{\prime}(\mathrm{Pa})$, loss modulus $\mathrm{G}^{\prime \prime}(\mathrm{Pa})$, loss tangent $\tan \delta\left(\mathrm{G}^{\prime \prime} / \mathrm{G}^{\prime}\right)$ and complex viscosity $\left|\eta^{*}\right|$ (Pa.s), as a function of the frequency $\mathrm{f}(\mathrm{Hz})$. From the later, $\log \alpha$ and $\mathrm{b}$ values were obtained by logarithmic fitting of experimental data to the Power Law according to Eq. 1 (Kasapis et al. 1997).

$\left|\eta^{*}\right|=\alpha \cdot \omega^{-b}$

The $\log \alpha$ value is a function of the viscoelastic properties that depends on the material consistency while the $b$ value reflects the dependency of viscoelastic properties on the frequency variation.

\section{Texture analysis}

A texture analyser TAHDi (Stable Micro Systems, Godalming, UK), equipped with a $250 \mathrm{~N}$ load cell, was used to perform the texture analysis at $20 \pm 1{ }^{\circ} \mathrm{C}$. The procedure was implemented by puncture with a $20 \mathrm{~mm}$ diameter aluminium cylindrical probe, at a penetration depth of $20 \mathrm{~mm}$ (the height of the sample was $50 \mathrm{~mm}$ ), with a crossed speed of $1 \mathrm{~mm} \mathrm{~s}^{-1}$ (Alvarenga \& Sousa, 2001). Texture measurements were performed in triplicate: one was performed on the core and the two others were performed closer to the rind of the cheese. Hardness values were obtained from the force vs. time texturograms (Van-Hekken et al. 2005).

\section{Colour measurement}

The colour analysis was performed using a colorimeter CR 300 (Minolta, Osaka, Japan). The $L^{*}, a^{*}$, and $b^{*}$ colour parameters were determined according to the CIELAB colour space, using a standard white tile $\left(L^{*}=97 \cdot 10, a^{*}=-4 \cdot 88\right.$, $\left.b^{*}=7 \cdot 04\right)$ for calibration (Pinho et al. 2004). Colour measurements were repeated ten times: five measurements in the core and another five near the rind of the cheese.

\section{Statistical analysis}

The average and standard deviation values were determined. Experimental data were subjected to One-way ANOVA (pairwise comparison of means with Scheffé test). Two different multivariate exploratory techniques were performed on the results: a principal component analysis (PCA), to identify the key parameters describing data variability, and a cluster analysis which will allow the evaluation of the impact of freezing on RESS-cheese characteristics. The level of significance, chosen for variable selection, was 0.05.
Data were analysed using STATISTICA 6.0 (StatSoft, Tulsa, USA).

\section{Results and Discussion}

\section{Impact of freezing on chemical properties}

Considering the chemical properties of frozen and NF cheese samples, one can observe that, in the majority of the cases, freezing did not affect the major components of cheese, like moisture, fat and $\mathrm{TN}$ (Table 1). These results are in agreement with results reported earlier by other authors who have studied the impact of freezing in cheese chemical properties (Van-Hekken et al. 2005).

The nitrogen fractions of the different samples are related to the enzymatic activity during the freezing period. With the results from the nitrogen fractions (Table 1) we would be able to understand if there was still some enzymatic activity during the freezing period.

The WSN\% fraction is a measure of the hydrolysis of peptides soluble in water, irrespective of their size. Its value has been traditionally regarded as a ripening index for cheese, as it reflects the extent of proteolysis, allowing its use as an indicator of the primary proteolysis (FérnandezSalguero \& Sanjuán, 1999: Pereira et al. 2008). NPN\% and AN\% fractions represent the depth of proteolysis, that is, to what degree the proteins and peptides are being degraded to intermediate- and small-sized peptides (2 to 20 amino acid residues) or to amino acids, used as indicators of the secondary proteolysis occurrence (Pereira et al. 2008). In the majority of cases, no significant differences were found for WSN\% results obtained for NF and frozen samples $(P>0.05)$ (Table 1$)$, with a primary proteolysis ranging from $25 \cdot 1$ to $34 \cdot 4 \%$ of $\mathrm{TN}$. These values are similar to those found by Sousa et al. (2001) and by Tavaria et al. (2003) for Serra da Estrela cheese, a similar Portuguese raw ewes'-milk semi-soft cheese. This evidences the fact that at $28 \mathrm{~d}$ of ripening, the shortest maturation time used in the experimental design to introduce the freezing process, the primary proteolysis process has already occurred to a greater extent. Because of that, it is possible to conclude that, if the freezing process is introduced after $28 \mathrm{~d}$ of ripening, it will not affect significantly the primary proteolysis of Serpa cheese.

However, one of the indicators of the secondary proteolysis, the NPN\%, presented significant differences between the NF and the frozen samples, with higher values in the frozen samples $(P<0.05)$ (Table 1$)$, meaning that the freezing process did not prevent the secondary proteolysis mechanisms from occurring; they continue to develop, as has been previously reported by other authors which studied the impact of freezing on proteolysis during cheese ripening (Bertola et al. 1996; Tejada et al. 2002; Verdini et al. 2003; Graiver et al. 2004; Van-Hekken et al. 2005; Verdini et al. 2005). Freezing led to higher NPN concentrations, probably due to the damage caused by the ice crystals on (1) casein matrix and (2) the starter cells that liberate proteolytic enzymes to the media (Graiver et al. 2004), making them 
more available for the enzymatic activity. This indicates that the overall freezing/frozen/thawing process did not prevent the secondary proteolysis of cheese.

Cheese samples which were frozen at $28 \mathrm{~d}$ of ripening presented lower $\mathrm{pH}$ values than the NF samples, which were significantly different from the NF samples in some cases (Table 1). This fact may possibly indicate that, in the samples where the freezing process has been introduced in an earlier stage of the maturation process, the $\mathrm{pH}$ increase at the end of ripening, characteristic of this type of cheese (Alvarenga et al. 2008), has been impaired.

A PCA was carried out on seven chemical properties to better evaluate the impact of freezing on the cheese samples, namely: moisture, $\mathrm{pH}$, fat, TN, WSN\%, NPN\% and AN\%. The similarity map defined by the first two principal components took into account $70 \cdot 7 \%$ of the total variance. The first component (PC1) by itself condensed $43 \cdot 3 \%$ and the second component (PC2) represented $27.4 \%$ of the total variance. PC1 has shown high negative correlation with moisture and fat, and high positive correlation with WSN\% and AN\%. PC2 has shown high negative correlation with TN and $\mathrm{pH}$.

Figure 1 shows the combined plot of scores and loadings on PC1 vs. PC2 obtained using the chemical parameters. The NF sample was positioned in the centre of the principal plan, relatively equidistant from the majority of the frozen samples, which means that freezing did not impact much on the chemical properties of cheeses. Taking a closer look at the samples positioned in the map, it is possible to see that the 20F42 and $20 S 42$ samples are clustered with the NF sample, indicating that these cheese samples, frozen after the $42 \mathrm{~d}$ of ripening at $-20{ }^{\circ} \mathrm{C}$, were the least damaged by the freezing process. In addition, from the results of the Euclidian distances between pairs of samples, the frozen samples with a shorter distance from the NF sample were the 20F42 and the 20S35, with a Euclidian distance of 0.88 and 0.89 , respectively. On the other hand, the samples with a larger distance from the NF sample were the 20F28 and 20S28, with Euclidian distances of $2 \cdot 0$ and $2 \cdot 2$, respectively. This means that for these seven properties the samples most damaged by the freezing process were the 20F28 and 20S28, and the least damaged were the 20F42, 20 S42 and 20 S35.

\section{Impact of freezing on physical properties}

All the frozen samples exhibited a mechanical spectrum similar to the NF samples (data not shown). In order to have an idea about the rheological behaviour of Serpa cheese, the mechanical spectrum of NF and one of the frozen samples (e.g. 20F42) is presented in Fig. 2. The variation of $\mathrm{G}^{\prime}$ and $\mathrm{G}^{\prime \prime}$ with frequency, for the frozen samples followed the same pattern as the NF samples, indicating a very weak structure (comparable to a concentrated suspension) in all samples, with a crossing point $\left(G^{\prime \prime}=G^{\prime}\right)$ at the low frequencies on the left side of the graphic, and both modulus highly dependent on the frequency. Additionally, data in Table 2 confirm that the differences between frozen and NF samples were not 


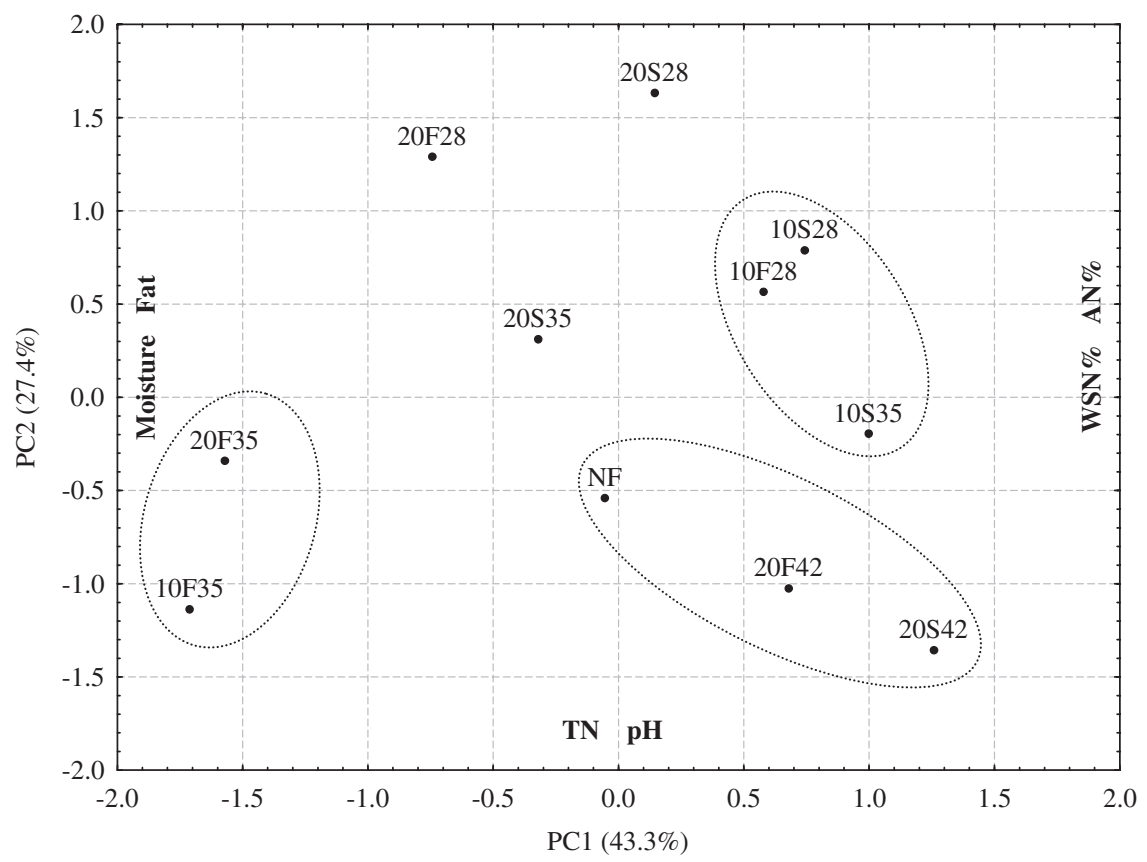

Fig. 1. PC1 vs. PC2 projection of samples (chemical attributes, mean values, $n=3$ ). The most important parameters for the definition of the two components are shown on the edge of each axis, indicating the direction in which the value of the parameter increases. Samples were clustered according to the results obtained from the hierarchical cluster analysis (linkage distance < 0.9). NF: non-frozen; 10 and 20: frozen storage temperature, $-10^{\circ} \mathrm{C}$ and $-20^{\circ} \mathrm{C}$, respectively; F: fast and S: slow freezing; 28,35 and $42 \mathrm{~d}$ of ripening.

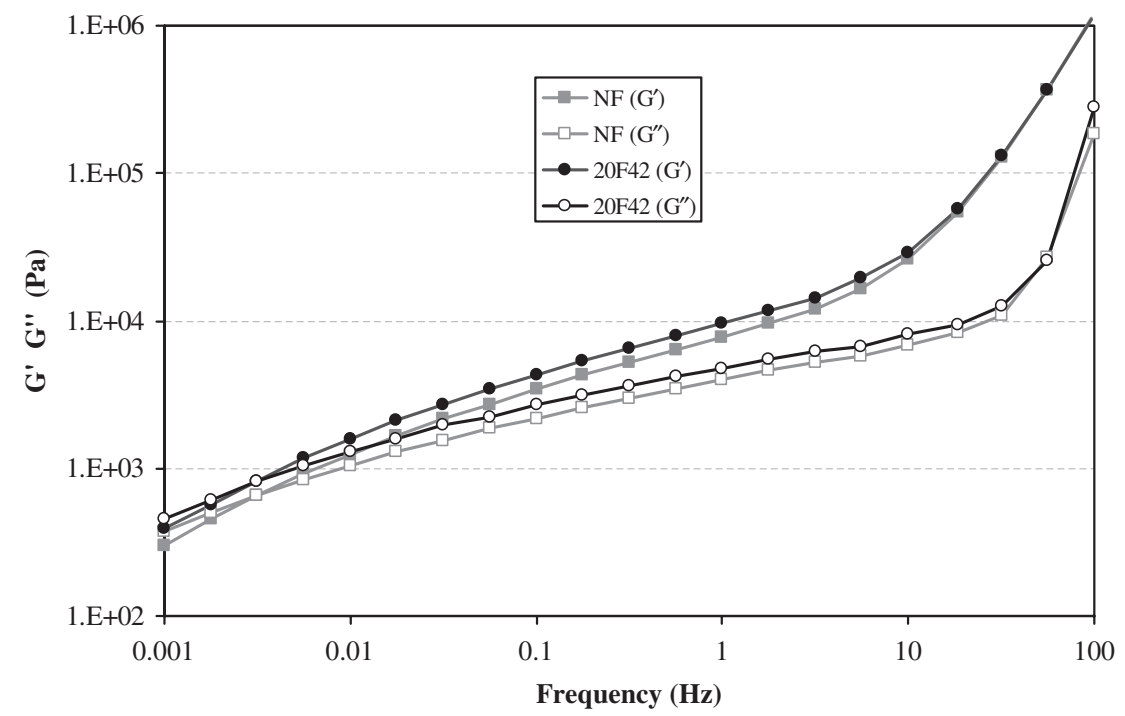

Fig. 2. Average mechanical spectrum of non-frozen samples, NF ( --$)$ and samples frozen after $42 \mathrm{~d}$ of ripening with fast freezing method and stored at $-20^{\circ} \mathrm{C}, 20 \mathrm{~F} 42(--)$.

significant for $\mathrm{G}_{1 \mathrm{~Hz}}^{\prime} \tan \delta_{1 \mathrm{~Hz}}, \log \alpha$ and b (Scheffé test, $P>0 \cdot 05)$.

When the hardness of these samples was measured, the structure of the frozen samples was significantly different from the NF samples $(P<0 \cdot 05)$. To explain the increase in hardness of the frozen samples, the mechanism proposed earlier by Diefes et al. (1993) seems appropriate: during the freezing process (temperature drop down), the formation of ice crystals gives rise to a local dehydration of proteins, inducing breaking of the protein structure. This allows the contact of the small fat globules with each other and the formation of fat granules. The proteins become more compact or interact to form disulphide bridges around new fat granules. Upon thawing, the proteins are unable to fully 
Table 2. Effect of freezing on Serpa cheese physical properties. Mean values (standard deviation). NF: non-frozen; 10 and 20 : frozen storage temperature, $-10{ }^{\circ} \mathrm{C}$ and $-20^{\circ} \mathrm{C}$, respectively; F: fast and S: slow freezing; 28,35 and $42 \mathrm{~d}$ of ripening

Samples

\begin{tabular}{|c|c|c|c|c|c|c|c|c|c|c|c|}
\hline & $\mathrm{NF}$ & $20 S 28$ & $10 S 28$ & $20 F 28$ & $10 \mathrm{~F} 28$ & $20 S 35$ & $10 S 35$ & 20F35 & 10F35 & $20 F 42$ & $20 S 42$ \\
\hline Hardness (N) & $\begin{array}{l}7.05^{\mathrm{c}} \\
(2.54)\end{array}$ & $\begin{array}{c}13.38^{\mathrm{ab}} \\
(3.36)\end{array}$ & $\begin{array}{c}13.88^{\mathrm{ab}} \\
(2.54)\end{array}$ & $\begin{array}{c}12.05^{\mathrm{b}} \\
(2.02)\end{array}$ & $\begin{array}{c}12.20^{\mathrm{b}} \\
(2.58)\end{array}$ & $\begin{array}{c}15.91^{\mathrm{ab}} \\
(2.41)\end{array}$ & $\begin{array}{c}16.58^{\mathrm{a}} \\
(2.83)\end{array}$ & $\begin{array}{c}13.75^{\mathrm{ab}} \\
(2.06)\end{array}$ & $\begin{array}{c}13.31^{\mathrm{ab}} \\
(1.94)\end{array}$ & $\begin{array}{c}12.9^{\mathrm{ab}} \\
(3.69)\end{array}$ & $\begin{array}{l}15.82^{\mathrm{ab}} \\
(2.82)\end{array}$ \\
\hline $\begin{array}{l}\text { Storage modulus } \\
\mathrm{G}^{\prime} \text { at } 1 \mathrm{~Hz}(\mathrm{kPa})\end{array}$ & $\begin{array}{l}7.81^{\mathrm{ab}} \\
(2.65)\end{array}$ & $\begin{array}{l}10.33^{\mathrm{ab}} \\
(2.95)\end{array}$ & $\begin{array}{c}7.09^{\mathrm{b}} \\
(3.09)\end{array}$ & $\begin{array}{l}9.23^{\mathrm{ab}} \\
(1.50)\end{array}$ & $\begin{array}{l}7.76^{\mathrm{ab}} \\
(1.55)\end{array}$ & $\begin{array}{l}10.86^{\mathrm{ab}} \\
(1.23)\end{array}$ & $\begin{array}{l}7.63^{\mathrm{ab}} \\
(1.82)\end{array}$ & $\begin{array}{r}11.74^{\mathrm{a}} \\
(1.65)\end{array}$ & $\begin{array}{l}9.90^{\mathrm{ab}} \\
(2.30)\end{array}$ & $\begin{array}{l}9.58^{\mathrm{ab}} \\
(1.68)\end{array}$ & $\begin{array}{l}11.23^{\mathrm{ab}} \\
(1.03)\end{array}$ \\
\hline $\tan \delta$ at $1 \mathrm{~Hz}$ & $\begin{array}{l}0.53^{\mathrm{ab}} \\
(0.071)\end{array}$ & $\begin{array}{l}0.49^{\text {ab }} \\
(0.046)\end{array}$ & $\begin{array}{l}0.56^{\mathrm{a}} \\
(0.063)\end{array}$ & $\begin{array}{r}0.52^{\mathrm{ab}} \\
(0.027)\end{array}$ & $\begin{array}{r}0.55^{\mathrm{ab}} \\
(0.047)\end{array}$ & $\begin{array}{r}0.47^{\mathrm{ab}} \\
(0.029)\end{array}$ & $\begin{array}{r}0.55^{\mathrm{ab}} \\
(0.046)\end{array}$ & $\begin{array}{l}0.47^{b} \\
(0.026)\end{array}$ & $\begin{array}{l}0.53^{\mathrm{ab}} \\
(0.044)\end{array}$ & $\begin{array}{r}0.50^{\mathrm{ab}} \\
(0.045)\end{array}$ & $\begin{array}{r}0.47^{\mathrm{ab}} \\
(0.011)\end{array}$ \\
\hline $\log \alpha$ & $\begin{array}{r}3.16^{a b} \\
(0.136)\end{array}$ & $\begin{array}{l}3.27^{\mathrm{ab}} \\
(0.118)\end{array}$ & $\begin{array}{l}3.11^{b} \\
(0.166)\end{array}$ & $\begin{array}{l}3.24^{\mathrm{ab}} \\
(0.066)\end{array}$ & $\begin{array}{r}3.17^{\mathrm{ab}} \\
(0.069)\end{array}$ & $\begin{array}{l}3.30^{\mathrm{ab}} \\
(0.054)\end{array}$ & $\begin{array}{r}3.16^{a b} \\
(0.086)\end{array}$ & $\begin{array}{l}3.34^{\mathrm{a}} \\
(0.053)\end{array}$ & $\begin{array}{r}3.27^{\mathrm{ab}} \\
(0.097)\end{array}$ & $\begin{array}{r}3.25^{\mathrm{ab}} \\
(0.063)\end{array}$ & $\begin{array}{l}3.32^{\mathrm{a}} \\
(0.038)\end{array}$ \\
\hline$b$ & $\begin{array}{r}0.58^{\mathrm{ab}} \\
(0.057)\end{array}$ & $\begin{array}{l}0.62^{a b} \\
(0.045)\end{array}$ & $\begin{array}{l}0.54^{\mathrm{b}} \\
(0.055)\end{array}$ & $\begin{array}{l}0.58^{\mathrm{ab}} \\
(0.025)\end{array}$ & $\begin{array}{l}0.56^{\mathrm{ab}} \\
(0.032)\end{array}$ & $\begin{array}{l}0.63^{\mathrm{a}} \\
(0.032)\end{array}$ & $\begin{array}{l}0.56^{\mathrm{ab}} \\
(0.034)\end{array}$ & $\begin{array}{l}0.62^{\mathrm{a}} \\
(0.026)\end{array}$ & $\begin{array}{l}0.59^{a b} \\
(0.046)\end{array}$ & $\begin{array}{l}0.60^{\mathrm{ab}} \\
(0.049)\end{array}$ & $\begin{array}{r}0.62^{\mathrm{ab}} \\
(0.015)\end{array}$ \\
\hline Colour-L* & $\begin{array}{l}77.7^{\mathrm{e}} \\
(1.228)\end{array}$ & $\begin{array}{c}79.5^{\mathrm{abc}} \\
(0.770)\end{array}$ & $\begin{array}{c}78.7^{\text {bcde }} \\
(0.736)\end{array}$ & $\begin{array}{l}80.1^{\mathrm{a}} \\
(1.364)\end{array}$ & $\begin{array}{l}79.9^{\mathrm{ab}} \\
(1.065)\end{array}$ & $\begin{array}{l}79.7^{\mathrm{ab}} \\
(1.207)\end{array}$ & $\begin{array}{l}78.3^{\text {cde }} \\
(1.403)\end{array}$ & $\begin{array}{l}79.9^{\mathrm{ab}} \\
(1.723)\end{array}$ & $\begin{array}{c}79.1^{\text {abcd }} \\
(1.450)\end{array}$ & $\begin{array}{l}78.3^{\text {cde }} \\
(0.391)\end{array}$ & $\begin{array}{l}78.1^{\text {de }} \\
(0.449)\end{array}$ \\
\hline Colour-a* & $\begin{array}{r}-3.88^{\mathrm{a}} \\
(0.323)\end{array}$ & $\begin{array}{r}-4.25^{\mathrm{b}} \\
(0.198)\end{array}$ & $\begin{array}{r}-4.69^{\mathrm{cd}} \\
(0.155)\end{array}$ & $\begin{array}{r}-4.41^{\mathrm{b}} \\
(0.165)\end{array}$ & $\begin{array}{r}-4.40^{\mathrm{b}} \\
(0.203)\end{array}$ & $\begin{array}{r}-4.44^{\mathrm{bc}} \\
(0.191)\end{array}$ & $\begin{array}{r}-4.44^{b c} \\
(0.335)\end{array}$ & $\begin{array}{r}-4.76^{\mathrm{d}} \\
(0.182)\end{array}$ & $\begin{array}{r}-4.88^{\mathrm{d}} \\
(0.279)\end{array}$ & $\begin{array}{r}-4.37^{b} \\
(0.129)\end{array}$ & $\begin{array}{r}-4.32^{b} \\
(0.194)\end{array}$ \\
\hline Colour-b* & $\begin{array}{l}13.07^{\mathrm{e}} \\
(2.072)\end{array}$ & $\begin{array}{l}14.9^{\mathrm{d}} \\
(0.542)\end{array}$ & $\begin{array}{r}16.82^{\mathrm{ab}} \\
(0.798)\end{array}$ & $\begin{array}{r}15.37^{\mathrm{cd}} \\
(0.492)\end{array}$ & $\begin{array}{r}15.95^{\mathrm{bc}} \\
(0.713)\end{array}$ & $\begin{array}{r}15.36^{\mathrm{cd}} \\
(0.563)\end{array}$ & $\begin{array}{l}17.05^{\mathrm{a}} \\
(0.547)\end{array}$ & $\begin{array}{c}16.02^{\mathrm{bc}} \\
(0.581)\end{array}$ & $\begin{array}{c}17.14^{\mathrm{a}} \\
(0.679)\end{array}$ & $\begin{array}{r}15.31^{\mathrm{cd}} \\
(0.537)\end{array}$ & $\begin{array}{c}14.98^{\mathrm{d}} \\
(0.790)\end{array}$ \\
\hline
\end{tabular}

$\mathrm{a}, \mathrm{b}, \mathrm{c}, \ldots$ Means in the same row marked with different letters are significantly different $(P<0 \cdot 05, n=9$, texture: $n=15$, colour: $n=30$ Scheffé test)

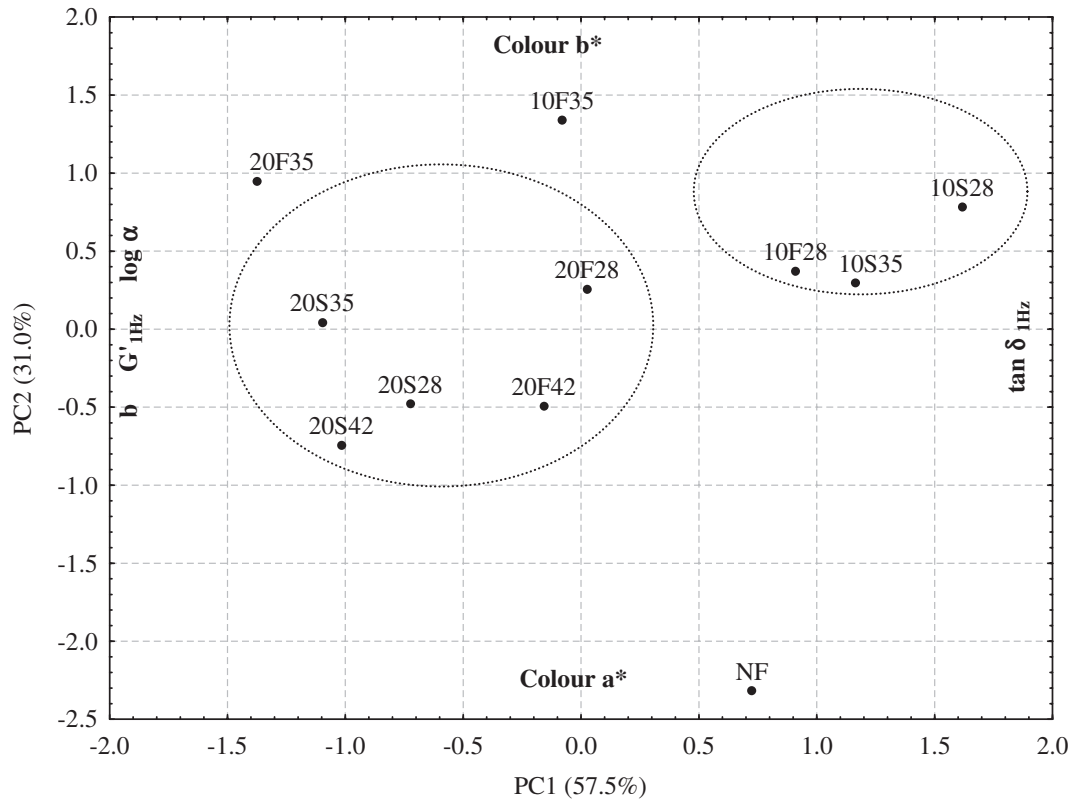

Fig. 3. PC1 vs. PC2 projection of samples (physical attributes, mean values, $n=3$ ). The most important parameters for the definition of the two components are shown on the edge of each axis, indicating the direction in which the value of the parameter increases. Samples were clustered according to the results obtained from the hierarchical cluster analysis (linkage distance <0.9). NF: non-frozen; 10 and 20: frozen storage temperature, $-10{ }^{\circ} \mathrm{C}$ and $-20^{\circ} \mathrm{C}$, respectively; F: fast and S: slow freezing; 28,35 and $42 \mathrm{~d}$ of ripening.

rebind water. This leads to a harder and more elastic cheese structure with less free oil. During frozen storage period, there is an increase in the crystal diameter due to ice recrystallization, thus making it more difficult for the relocation of water at the lipid-casein interface after thawing, diminishing its lubricant effect and thus producing a harder cheese structure.
Concerning colour parameters (Table 2), the freezing process has affected the frozen samples. The frozen samples presented significantly lower values for the colour parameter $a^{*}$ (i.e. more green) and significantly higher values for the colour parameter $b^{*}$ (i.e. more yellow) than the NF samples $(P<0 \cdot 05)$. The colour parameter $L^{*}$ was also higher for the frozen samples looking lighter; however significant 
differences from the NF samples were only observed in some cases. As a consequence, the colour of the frozen samples was more luminous and more yellow-green than the NF samples colour.

A PCA was carried out on seven physical properties (colour parameters $\mathrm{L}^{*}, \mathrm{a}^{*}$ and $\mathrm{b}^{*}$, and viscoelastic parameters $\mathrm{G}_{1 \mathrm{~Hz}}^{\prime} \tan \delta_{1 \mathrm{~Hz}}, \log \alpha$ and b. The similarity map defined by the first two principal components took into account $88.5 \%$ of the total variance (Fig. 3). The first component (PC1) by itself condensed $57.5 \%$ and the second component (PC2) represented $31 \cdot 0 \%$ of the total variance.

The PC1 was explained by rheological data and the PC2 was explained by chromatic parameters ( $a^{*}$ and $\left.b^{*}\right)$. The PC1 had negative correlations with $\mathrm{G}_{1 \mathrm{~Hz}}^{\prime} \log \alpha$ and $\mathrm{b}$, and positive correlations with $\tan \delta_{1 \mathrm{~Hz}}$. The PC2 was negatively correlated to $\mathrm{a}^{*}$ and positive correlated to $\mathrm{b}^{*}$.

The PC2 was able to separate the frozen from the NF samples, supporting that freezing affected mainly colour parameters. Furthermore, the majority of the frozen samples were located on the left side of the plan, in the negative part of the PC1 axis, pointing to the strengthening of the cheese structure after freezing, already explained with the texture data. This was even more evident for the cheese samples frozen at $-20{ }^{\circ} \mathrm{C}$, which were clustered together in the left side of the PCA map. The Euclidian linkage distances between pairs of samples allowed us to verify that the samples $20 S 42$ and 20F42 were the closest to the NF sample, with Euclidian distances of $2 \cdot 0$ and $2 \cdot 3$, respectively, and that the samples 10F35 and 20F35 were the ones situated with a greater distance to the NF sample, 3.7 and $3 \cdot 9$, respectively.

Taking into account the PCA results from chemical and physical properties (Fig. 1 \& 3), the samples $20 \mathrm{~F} 42$ and $20 S 42$ were the ones most similar to the NF samples. This means that, if the freezing was introduced at the end of ripening (42 d), using a frozen storage temperature of $-20{ }^{\circ} \mathrm{C}$, damages to Serpa cheese properties are minimized. At these freezing conditions, no significant differences were found, for the chemical and physical properties, between the samples subjected to different freezing methods, slow or fast $(P>0 \cdot 05)$ (Tables $1 \& 2)$.

\section{Conclusions}

From this study it is possible to conclude that frozen storage did not affect the major components of Serpa cheese. However, a significant effect on NPN\%, hardness and colour was observed: frozen samples showed high values of NPN\% and hardness, and they were more luminous and more yellow-green than the NF samples. These effects were less pronounced if the freezing was introduced at the end of ripening (42 d), using a frozen storage temperature of $-20{ }^{\circ} \mathrm{C}$. Moreover, using these freezing conditions, no significant differences were found, for the chemical and physical properties, between the samples subjected to different freezing methods, slow or fast.
Further studies are needed in order to ascertain if the differences found using the worst case scenario of this study are likely to be detected by the consumers, or what would be the maximum frozen storage time, under the selected conditions, that would make the differences undetectable by the consumers.

\section{References}

Alvarenga N, Silva P, Rodriguez-Garcia J \& Sousa I 2008 Estimation of Serpa cheese ripening time using multiple linear regression (MLR) considering rheological, physical and chemical data. Journal of Dairy Research $\mathbf{7 5}$ 233-239

Alvarenga NB \& Sousa IM 2001 Evaluation of texture measurements of soft cheese. In XIIt International Congress on Rheology, Vol. IV, pp. 392-394. Cambridge, UK

AOAC 1990 Official Methods of Analysis (15th edition). Washington: Association of Official Analytical Chemists

Bertola NC, Califano AN, Bevilacqua AE \& Zaritzky NE 1996 Textural changes and proteolysis of low-moisture Mozzarella cheese frozen under various conditions. Lebensmittel-Wissenschaft und-Technologie 29(5-6) $470-474$

Cunha CR, Viotto WH \& Viotto LA 2006 Use of low concentration factor ultrafiltration retentates in reduced fat "Minas Frescal" cheese manufacture: Effect on composition, proteolysis, viscoelastic properties and sensory acceptance. International Dairy Journal 16(3) 215-224

Diefes HA, Rizvi SSH \& Bartsh JA 1993 Rheological behaviour of frozen and thawed low-moisture part skim, Mozzarella cheese. Journal of Food Science 58 764-769

Fennema O (1972) Freezing of cheese - pros and cons. In Marschall Italian and Specialty Cheese Seminar Madison - Wisconsin

Férnandez-Salguero J \& Sanjuán E 1999 Influence of vegetable and animal rennet on proteolysis during ripening in ewe's milk cheese. Food Chemistry 64 177-183

Fontecha J, Bellanato J \& Juarez M 1993 Infrared and Raman spectroscopic study of casein in cheese: effect of freezing and frozen storage. Journal of Dairy Science 76 3303-3309

Freitas AC, Fresno JM, Prieto B, Malcata FX \& Carballo J 1997 Effects of ripening time and combination of ovine and caprine milks on proteolysis of Picante cheese. Food Chemistry 60(2) 219-229

Graiver NG, Zaritzky NE \& Califano AN 2004 Viscoelastic behavior of refrigerated frozen low-moisture Mozzarella cheese. Journal of Food Science 69(3) 123-128

ISO 3432 (1975) Cheese-Determination of Fat Content-Butyrometer for Van Gulik Method. Geneva, Switzerland: International Organization for Standardization

Kasapis S, Paraskevopoulou A, Kiosseoglou A \& Alevipoulus S 1997 Small deformation properties of model salad dressing prepared with reduced cholesterol egg yolk. Journal of Texture Studies 28 221-237

Kuchroo CN \& Fox PF 1982 Soluble nitrogen in Cheddar cheese: comparison of extraction procedures. Milchwissenschaft 37 331-335

Park YW 2007 Rheological characteristics of goat and sheep milk. Small Ruminant Research 68(1-2) 73-87

Pearce KN, Karahalios D \& Friedman M 1988 Ninhydrin assay for proteolysis in ripening cheese. Journal of Food Science $\mathbf{5 3}$ 432-438

Pereira CI, Gomes EO, Gomes AMP \& Malcata FX 2008 Proteolysis in model Portuguese cheeses: Effects of rennet and starter culture. Food Chemistry 108(3) 862-868

Pinho O, Mendes E, Alves MM \& Ferreira IMPLVO 2004 Chemical, physical and sensorial charateristics of "Terrincho" ewe cheese: Changes during ripening and intravarietal comparioson. Journal of Dairy Science 87(1) $1-9$

Prados F, Pino A, Rincon F, Vioque M \& Fernandez-Salguero J 2006 Influence of the frozen storage on some characteristics of ripened 
Manchego-type cheese manufactured with a powdered vegetable coagulant and rennet. Food Chemistry 95(4) 677-682

Ribero GG, Rubiolo AC \& Zorrilla SE 2007 Influence of immersion freezing in $\mathrm{NaCl}$ solutions and of frozen storage on the viscoelastic behaviour of Mozzarella cheese. Journal of Food Science 72(5) 301-307

Roseiro LB, Wilbey RA \& Barbosa M 2003 Serpa cheese: Technological, biochemical and microbiological characterisation of a PDO ewe's milk cheese coagulated with Cynara cardunculus L. Lait 83 469-481

Rosenberg M, Wang Z, Chuang SL \& Shoemaker CF 1995 Viscoelastic property changes in Cheddar cheese during ripening. Journal of Food Science 60(3) 640-644

Sousa MJ, Ardo Y \& McSweeney PLH 2001 Advances in the study of proteolysis during cheese ripening. International Dairy Journal 11(4-7) 327-345

Tavaria FK, Francob I, Carballob FJ \& Malcata FX 2003 Amino acid and soluble nitrogen evolution throughout ripening of Serra da Estrela cheese. International Dairy Journal 13 537-545

Tejada L, Gomez R, Vioque M, Sanchez E, Mata C \& Fernandez-Salguero J 2000 Effect of freezing and frozen storage on the sensorial characteristics of los Pedroches, a Spanish cheese. Journal of Sensory Studies 15(3) 251-262
Tejada L, Sanchez E, Gomez R, Vioque M \& Fernandez-Salguero J 2002 Effect of freezing and frozen storage on chemical and microbiological characteristics in sheep milk cheese. Journal of Food Science 67(1) 126-129

Van-Hekken DL, Tunick MH \& Park YW 2005 Effect of frozen storage on the proteolytic and rheological properties of soft caprine milk Cheese. Journal of Dairy Science 88 1966-1972

Verdini RA, Zorrilla SE \& Rubiolo AC 2003 Changes in equilibrium modulus and $\alpha_{\mathrm{s} 1}$-casein breakdown during the ripening of Port Salut Argentino cheese as affected by frozen storage. Journal of Texture Studies $\mathbf{3 4}$ 331-346

Verdini RA, Zorrilla SE \& Rubiolo AC 2005 Effects of the freezing process on proteolysis during the ripening of Port Salut Argentino cheeses. International Dairy Journal 15(4) 363-370

Zalazar CA, Zalazar CS, Bernal S, Bertola N, Bevilacqua A \& Zaritzky N 2002 Effect of moisture level and fat replacer on physicochemical, rheological and sensory properties of low fat soft cheeses. International Dairy Journal 12(1) 45-50

Zhang RH, Mustafa AF, Ng-Kwai-Hang KF \& Zhao X 2006 Effects of freezing on composition and fatty acid profiles of sheep milk and cheese. Small Ruminant Research 64(3) 203-210 
Reproduced with permission of the copyright owner. Further reproduction prohibited without permission. 